\title{
Pengaruh KaraKter KerJa Keras TerhadaP KeMAMPUAN Literasi MATEMATIS SiSWA MELALUi MODEL DISCOVERY LEARNING
}

\author{
Buyung ${ }^{1)}$, Resy Nirawati ${ }^{2)}$ \\ 1) Program Studi Pendidikan Matematika, STKIP Singkawang, Indonesia \\ E-mail: 21.buyung@gmail.com \\ 2) Program Studi Pendidikan Matematika, STKIP Singkawang, Indonesia \\ E-mail : resynirawaty@gmail.com
}

\begin{abstract}
Abstrak. Penelitian ini bertujuan untuk menguji pengaruh karakter kerja keras terhadap kemampuan literasi matematis siswa melaui pembelajaran model discovery learning. Jenis penelitian kuantitatif yang digunakan adalah penelitian eksperimen dengan True experimental design dengan bentuk posttest-only control design. Subjek penelitiannya adalah siswa kelas VIII SMP Negeri 1 Sanggau Ledo, Kalimantan Barat. Pengambilan data dengan melakukan tes kemampuan literasi matematis serta angket dan observasi untuk karakter kerja keras pada tiap sampel. Hasil penelitian menunjukan bahwa persamaan regresi mengambarkan persamaan regresi $\mathrm{y}^{\wedge}=\mathrm{a}+\mathrm{bx}$ dimana $\mathrm{a}=15.045$ dan $\mathrm{b}=0.830$ sehingga dimasukan ke persamaan $\mathrm{y}^{\wedge}=$ $15.045+0.830 \mathrm{x}$. nilai signifikansi sebesar $0.000<0.05$. Sedangkan ketuntasan klasikal diperoleh nilai Zhitung $=1,89$. dibandingkan ztabel $=1,645$ dengan taraf kesalahan 5\% atau 1,89>1,645, maka H0 ditolak. Artinya, proporsi siswa yang mendapat nilai TKLM lebih dari atau sama dengan KKM $=70$ telah melampaui $75 \%$.
\end{abstract}

Kata kunci: Discovery Learning, kemampuan aliterasi, karakter, kerja keras

\section{PENDAHULUAN}

Matematika mempunyai arti penting dalam membantu manusia menyelesaikan masalah pada kehidupan sehari-hari. Konsep-konsep pada ilmu matematika dapat diterapkan untuk memecahkan masalah yang sedang dihadapi. Oleh karena itu, hendaknya pembelajaran matematika di kelas tidak hanya menitikberatkan pada penguasaan materi untuk menyelesaikan masalah secara matematis. Tetapi juga membuat siswa lebih memahami konsep pada ilmu matematika itu sendiri dan membuat siswa lebih mengenal permasalahan-permasalahan dalam kehidupan sehari-hari yang dapat dipecahkan dengan pengetahuan matematika yang diperoleh siswa di sekolah.

Keberhasilan siswa Indonesia selama ini banyak dinilai masyarakat dari sisi dalam negeri saja, misalnya keberhasilan siswa-siswi dalam menghadapi ujian nasional yang masih menjadi standar penilaian pendidikan oleh masyarakat awam, namun sebenarnya pendidikan tidak dapat dinilai maupun dipandang dari ruang lingkup yang sempit. Sebab masih kurangnya siswa Indonesia yang kurang menyelesaikan masalah yang berkaitan dengan kehidupan sehari-hari. Hal ini terlihat pada rendahnya nilai matematika Indonesia dalam studi komparatif internasional PISA (Programme for International Student Assesment).
Programme for International Student Assessment (PISA) adalah Salah satu penilaian internasional yang masih berjalan hingga kini yang diselenggarakan oleh Organisation for Economic Co-operation and Development (OECD). PISA merupakan survei tiga tahunan yang menilai pengetahuan dan keterampilan siswa usia 15 tahun (OECD, 2007). PISA merupakan studi internasional dalam membaca (reading literacy), matematika (mathematics literacy), pemecahan masalah (problem solving literacy), dan sains (science literacy), dan yang terbaru adalah mengenai keuangan (financial literacy) (OECD, 2012).

Fokus dari PISA adalah literasi yang menekankan pada keterampilan dan kompetensi siswa yang diperoleh dari sekolah dan dapat digunakan dalam kehidupan sehari-hari dan dalam berbagai situasi. Literasi atau melek matematika pada draft assessment framework PISA 2012 diartikan sebagai kemampuan seseorang individu untuk merumuskan, menerapkan, dan menafsirkan matematika dalam berbagai konteks, termasuk kemampuan melakukan penalaran secara matematis dan menggunakan konsep, prosedur, fakta, dan alat matematika untuk menggambarkan, menjelaskan atau memperkirakan fenomena/kejadian. 
Menurut Wei \& ChunTai (2015) literasi matematika merupakan cakupan penalaran seseorang secara matematis dan menggunakan konsep matematika, prosedur, fakta, dan alat-alat untuk menggambarkan, menjelaskan fenomena serta membantu seseoraang dalam mengenali peran bahwa dalam matematika membuat keputusan membutuhkan konstruktif. Ojose (2011) menyatakan bahwa.

"Mathematics literacy is the knowledge to know and apply basic mathematics in our everday living". Pernyataan tersebut dapat diartikan literasi matematika merupakan pengetahuan untuk mengetahui dan menerapkan matematika dasar dalam kehidupan sehari-hari. Kemampuan ini juga berfokus kepada kemampuan siswa dalam menganalisa, memberikan alasan, dan menyampaikan ide secara efektif, merumuskan, memecahkan, dan menginterpretasi masalah-masalah matematika dalam berbagai bentuk dan situasi.

OECD (2013a) menyatakan bahwa dalam mengukur kemampuan literasi matematika, PISA mengacu pada tiga domain utama. Ketiga domain tersebut adalah domain konten, domain konteks, dan domain proses. Domain konten mencakup empat hal, yaitu bilangan (quantity), ruang dan bentuk (space and shape), perubahan dan hubungan (change and relationship), dan probabilitas/ketidakpastian (uncertainty) (OECD, 2013b). Domain konteks PISA terbagi menjadi empat hal, yaitu pribadi, pekerjaan, masyarakat, dan ilmiah (OECD, 2013b), sedangkan pada domain proses PISA membagi menjadi tiga macam yaitu merumuskan situasi secara matematis; menerapkan konsep, fakta, prosedur, dan penalaran matematika; serta menginterpreasi, menerapkan, dan mengevaluasi hasil matematis (OECD, 2013b). Selain ketiga domain proses tersebut, ada pula komponen-komponen literasi matematika yang perlu diperhatikan, yaitu: communication; mathematizing; representation; reasoning and argument; devising strategies for solving problems, using symbolic, formal, and technical language and operation; dan using mathematics tools (OECD, 2013b).

Kemampuan literasi matematis dianggap sebagai salah satu komponen penting yang dibutuhkan siswa untuk dapat berhasil memecahkan masalah dalam kehidupan sehari-hari. Apabila dicermati, tujuan mata pelajaran matematika menurut Standar Isi (SI) menunjukkan bahwa kurikulum yang disusun sudah memperhatikan aspek literasi matematika. Jadi tujuan mata pelajaran matematika menurut SI pada intinya juga merupakan kemampuan literasi matematika. Akan tetapi, tujuan mata pelajaran matematika dalam SI yang secara tidak langsung bertujuan agar siswa mempunyai kemampuan literasi matematika yang tinggi, pada kenyataannya berdasarkan hasil PISA menunjukkan kemampuan literasi matematika siswa Indonesia masih terkategori rendah.
Berdasarkan studi PISA (Program for internasional student Assessment), hasil yang dicapai siswa Indonesia jauh dari memuaskan. Pada pelaksanaan PISA 2015, Indonesia hanya mampu mencapai posisi 62 dari 70 negara yang berpartisipasi dengan skor 386 (OECD, 2016). Berdasarkan hasil pengamatan guru di kelas VIII di SMP N 1 Sanggau Ledo diperoleh berbagai hal pada proses pembelajaran matematika. Fakta yang ditemukan di antaranya siswa cenderung pasif, rendahnya antusiasme, dan kesulitan memahami materi. Hal tersebut diduga siswa belum sepenuhnya memiliki kemampuan literasi terutama pada tahap pemodelan dan penelaran untuk memecahkan masalah berkaitan dengan kehidupan sehari-hari, menyebabkan nilai rata-rata ulangan siswa banyak yang di bawah KKM. Pada aspek lain terlihat bahwa kemampuan literasi tiap individu yang belum maksimal dalam mengaplikasikan materi pembelajaran ke dalam kehidupan sehari-hari. Hal ini ditunjukkan dari lemahnya kemampuan siswa dalam mencari alternatif pemecahan masalah jika menemukan kesulitan.

Kerja keras adalah perilaku yang menunjukkan upaya sungguh-sungguh dalam mengatasi hambatan belajar, tugas, guna menyelesaikan tugas (belajar/bekerja) dengan sebaikbaiknya (Kemdiknas, 2010). Suatu fakta bahwa proses pembelajaran matematika siswanya cenderung pasif. Hal ini dapat dilihat bahwa siswa mengerjakan soal latihan jika diminta.

Sementara itu, kubus dan balok merupakan bagian dari materi matematika SMP kelas VIII semester genap yang menuntut pemikiran siswa untuk menemukan konsep secara teliti dalam menyelesaikan soal-soal yang berkaitan dengan volum kubus dan balok. Pembelajaran geometri sangat bermanfaat bagi siswa, khususnya sebagai dasar untuk menguasai, mempelajari dan memahami materi matematika yang lain maupun konsep bagun ruang di jenjang pendidikan yang lebih tinggi. Siswa di sekolah menengah pada umumnya mengalami kesulitan dalam mempelajarinya. Hal tersebut sering dianggap sepele oleh siswa maupun guru, bahkan guru yang terus melanjutkan materi tanpa memperhatikan dan mencari tahu apakah siswa pada umumnya telah memahami materi atau tidak, sehingga kesulitan atau kesalahan yang mungkin dilakukan siswa terus berlanjut hingga ke materi selanjutnya. Kesulitan siswa tersebut perlu mendapat perhatian khusus karena dapat berdampak pada rendahnya pemahaman fakta, konsep, aturan dan prosedur geometri selanjutnya yang lebih kompleks.

Selain itu model pembelajaran yang dapat meningkatkan literasi matematis dan kerja keras di antara siswa untuk saling memotivasi dan membantu menguasai materi pembelajaran adalah pembelajaran discovery learning. Model Discovery Learning (DL) merupakan salah satu model pembelajaran 
yang dapat memfasilitasi kemampuan literasi matematis dan kerja keras siswa dalam pembelajaran (Joy, 2014). Pembelajaran discovery memiliki kelebihan diantaranya yaitu menjadikan siswa lebih aktif dalam pembelajaran karena siswa dituntut untuk mengkaitkan pengetahuan baru dengan pengetahuan yang dimiliki sebelumnya untuk menemukan konsep. Hal ini menjadikan pembelajaran menjadi lebih bermakna dan memotivasi munculnya kemauan siswa untuk bekerja keras dalam matematika.

Sehingga dengan hal tersebut maka pembelajaran diharapkan akan menyenangkan dan siswa lebih mudah memahami materi yang dipelajari. Dalam menerapkan pembelajaran DL siswa yang mengalami kesulitan pada proses pembelajaran diberikan bantuan secara bimbingan.

Gambaran permasalahan di atas menunjukkan bahwa begitu pentingnya kemampuan literasi matematis dan kerja keras dalam pembelajaran matematika, membuat peneliti tertarik untuk mengungkap lebih jauh mengenai kemampuan literasi matematis siswa melalui suatu penelitian. Upaya pembelajaran sangat penting bagi seorang pendidik untuk melaksanakan fase awal pembelajaran. Fase ini merupakan tahap seorang pendidik mengetahui dan memahami bekal awal yang dimiliki siswanya. Bekal awal yang termasuk ke dalam tahap tersebut yaitu mengetahui potensi siswa dalam belajar. Pandangan ini mendukung dilakukannya penelitian mengenai potensi kemampuan literasi matematis dan kerja keras siswa.

Berdasarkan uraian di atas, tujuan dari penelitian ini yaitu: (1) menguji pengaruh karakter kerja keras terhadap kemampuan literasi matematis siswa melaui pembelajaran model discovery learning, dan (2) menguji kriteria ketuntasan minimal (KKM) kemampuan literasi matematis siswa melalui model mpembelajaran discovery learning. Matematika masih dianggap sebagai pelajaran yang sulit sehingga berdampak pada rendahnya kemampuan pemahaman matematis peserta didik. Salah satu upaya untuk mengatasi kesulitan peserta didik dalam memahami dan menyelesaikan masalah matematika adalah dengan mengajarkan matematika secara menarik dan terhubung dunia nyata.

\section{Metode Penelitian}

Penelitian ini merupakan penelitian eksperimen yang dilakukan pada dua kelompok siswa yang memiliki kemampuan serata denagn pembelajaran berbeda. Maka desain kerja pada penelitian ini haruslah dirancang secara terperinci agar saat pelaksanaan dapat memberikan hasil yang memuaskan. Adapun desain penelitian ini adalah True Experimental Design dengan bentuk Posttest-only control design dapat digambarkan sebagai berikut.

\begin{tabular}{c|ccc}
\hline & Kelompok & Perlakuan & Post-test \\
\hline Acak & $\mathrm{E}$ & $\mathrm{X}$ & $\mathrm{O}$ \\
Acak & $\mathrm{K}$ & $\mathrm{K}$ & $\mathrm{O}$ \\
& & & \\
\hline \multicolumn{4}{|c}{ Gambar 1. Posttest-only control design }
\end{tabular}

Menurut Sugiyono (2015) metode kuantitatif digunakan untuk menentukan populasi dan sampel sebagai tempat untuk menguji hipotesis, mengembangkan dan menguji instrumen dalam mengumpulkan data, analisis data, dan selanjutnya diakhiri dengan membuat kesimpulan dan saran. Metode kuantitatif dalam penelitian ini digunakan untuk mengetahui keefektifan pembelajaran inkuiri dengan strategi scaffolding. Perangket pembelajaran berupa silabus, RPP, LKS, dan soal tes kemampuan literasi matematika perlu dibuat terlebih dahulu kemudian dilakukan uji validitas oleh validator ahli untuk kemudian digunakan dalam penelitian. Populasi adalah keseluruhan subjek penelitian (Arikunto, 2010). Populasi dalam penelitian ini adalah seluruh siswa kelas VIII SMP Negeri 1 Sanggau Ledo yang terdiri dari 4 kelas yaitu VIIIA, VIIIB, VIIIC, dan VIIID.

Sampel adalah sebagian atau wakil populasi yang diteliti (Arikunto, 2010). Pengambilan sampel dalam penelitian ini adalah teknik random sampling, yaitu mengambil dua kelas dari kelas VIII SMP Negeri 1 Sanggau Ledo tahun pelajaran 2016-2017. Kelas yang pertama di dalam kegiatan mengajar mendapatkan pembelajaran DL yaitu kelas VIII B dan kelas yang kedua di dalam kegiatan mengajar mendapatkan pembelajaran ekspositori yaitu kelas VIII C. Data yang diperoleh diuji pengaruh menggunakan regresi sederhana. ketuntasan klasikal menggunakan uji Z.

\section{HASIL DAN PEMBAHASAN}

Tingkat signifikansi koefisien korelasi satu sisi dari output SPSS sebesar $0.000<0.05$ maka korelasi antara karakter kerja keras dengan kemampuan literasi sangat nyata. Berikut disajikan Tabel I.

\begin{tabular}{lccc} 
& $\begin{array}{c}\text { TABEL I } \\
\text { ANOVA }\end{array}$ & & \\
\hline Model & $\begin{array}{c}\text { Mean } \\
\text { Square }\end{array}$ & F & Sig. \\
\hline Regression & 590.957 & 31.918 & $.000^{\mathrm{a}}$ \\
Residual & 18.515 & & \\
Total & & \\
\end{tabular}




\section{- - - Jurnal Pendidikan Matematika Indonesia \\ Volum 3 Nomor 1 bulan Maret 2018 Page 21 - 25 \\ p-ISSN: 2477-5967 e-ISSN: 2477-8443}

Karena probabilitas $(0.000<0,05$, maka model regresi bisa dipakai untuk memprediksi variabel Y (kemampuan literasi). Berikut Tabel II persamaan regresi.

TABEL III

PERSAMAAN REGRESI

\begin{tabular}{lcccc}
\hline \multicolumn{5}{c}{$\begin{array}{c}\text { Unstandardized } \\
\text { Coefficients }\end{array}$} \\
Model & $\mathrm{B}$ & Std. Error & $\mathrm{t}$ & \multicolumn{1}{c}{ Sig. } \\
\hline (Constant & 15.04 & 10.777 & 1.39 & 174 \\
)$^{\mathrm{X}}$ & .830 & .147 & 5.65 & .000 \\
\hline
\end{tabular}

Persamaan regresi $\mathrm{y}^{\wedge}=\mathrm{a}+\mathrm{bx}$ dimana $\mathrm{a}=15.045$ dan $\mathrm{b}=$ 0.830 sehingga dimasukan ke persamaan $\mathrm{y}^{\wedge}=15.045+0.830$ x. sehingga dapat disimpulkan bahaw H0 ditolak dan terima $\mathrm{H}$, yang bearti bahwa terdapat pengaruh yang signifikan antara variabel karakter kerja keras dan variabel kemampuan literasi matematis.

Suatu kelas dikatakan tuntas belajarnya (ketuntasan klasikal) jika dalam kelas tersebut terdapat $\geq 75 \%$ siswa yang telah tuntas belajarnya. Uji ini dilakukan untuk mengetahui apakah nilai TKLM siswa yang mendapatkan minimal lebih dari atau sama dengan KKM mencapai sekurang-kurangnya $75 \%$. Dengan: $\mathrm{n}=30 ; \pi \_0=0,75 ; \mathrm{x}=27$. Jadi diperoleh nilai Zhitung $=1,89$. dibandingkan ztabel $=1,645$ dengan taraf kesalahan $5 \%$ atau $1,89>1,645$, maka H0 ditolak. Artinya, proporsi siswa yang mendapat nilai TKLM lebih dari atau sama dengan KKM $=70$ telah melampaui $75 \%$.

perbedaan rata-rata kemampuan literasi matematis. Berdasarkan hasil perhitungan diperoleh nilai rata-rata siswa pada kelas pembelajaran DL adalah 75,55 dan nilai rata-rata siswa pada kelas dengan pembelajaran ekspositori adalah 70,55 .

Jadi thitung $=3,04>$ ttabel $=1,671$. Hal ini berarti $\mathrm{H} 0$ ditolak, atau rataan kemampuan literasi matematis siswa yang diajarkan dengan pembelajaran DL lebih dari rataan kemampuan literasi matematis siswa yang diajarkan dengan pembelajaran lain. Berikut hasil uji Independent Samples Test kemampuan literasi siswa nilai signifikan 0,012<0,05. Kesimpulan yang diperoleh bahwa rata-rata kemampuan literasi matematika siswa pada kelas dengan pembelajaran DL lebih dari kemampuan literasi matematika siswa pada kelas kontrol.

Berdasarkan uji Pengaruh karakter kerja keras terhadap kemampuan literasi matematis diperoleh melalui data hasil pengisian kuesioner kerja keras dan observasi serta tes kemampuan literasi matematis. Berdasarkan analisis terhadap karakter kerja keras siswa bahwa secara rata-rata setiap pertemuan kegiatan pembelajaran mengalami peningkatan.

Uji regresi sederhana dilakukan untuk melihat hubungan linier antara variabel bebas $\mathrm{X}$ dengan variabel tidak bebas $\mathrm{Y}$ dan memprediksi nilai variabel tidak bebas $\mathrm{Y}$ dari nilai yang diberikan variabel bebas $\mathrm{X}$. sebelum melakuakan uji regresi sederhana asumsi-asumsi dasar yang harus dipenuhi sebelum melakaukan analisis linier sederhana adalah uji linieritas, uji normalitas dan uji homogenitas. Dari ketiga asumsi tersebut hasil menunjukan bahwa sudah terpenuhi. uji regresi sederhana berdasarkan analisis terdapat pengaruh yang signifikan antara variabel karakter kerja keras dan variabel kemampuan literasi matematis.

Hasil penelitian ini senada dengan hasil penelitian Cahyaningros (2013) yang mengungkapkan karakter kerja keras dan keterampilan berpikir kritis secara bersama-sama berpengaruh positif terhadap kemampuan berpikir kritis. Begitu pula hasil penelitian Taneo (2015) terdapat pengaruh karakter kerja keras terhadap kemampuan pemecahan masalah dengan besarnya pengaruh $56.3 \%$.

Hasil pengujian ketuntasan belajar, kelompok siswa dengan pembelajaran DL rata-rata nilai TKLM mencapai Kriteria Ketuntasan Minimal (KKM). Sedangkan berdasarkan uji ketuntasan klasikal menunjukan bahwa kelompok siswa dengan pembelajaran DL mencapai ketuntasan klasikal.

Berdasarkan perbedaan rata-rata kedua kelas yang diberikan perlakuan dengan kelas kontrol bahwa hasil menunjukan bahwa kelas yang diberika perlakuan pembelajaran DL lebih baik dari pada kelas kontrol. Dari hasil posttest kemampuan rata-rata kelas eksperimen sebesar 75,55 sedangkan untuk kelas kontrol sebesar 70,55. Dengan demikian bahwa rata-rata kelas eksperimen lebih besar dari kelas kontrol.

\section{IV.SIMPULAN}

Berdasarkan analisis hasil penelitian, dalam pembelajaran discovery learning di SMP Negeri 1 Sanggau Ledo dapat disimpulkan bahwa terdapat pengaruh yang positif yang signifikan antara kerja keras terhadap kemampuan literasi matematis siswa. Kemampuan literasi matematis siswa mencapai ketuntasan minimal (KKM) melalui model mpembelajaran discovery learning. Pembelajaran discovery learning dapat dijadikan alternatif model pembelajaran bagi guru untuk diterapkan di kelas dalam rangka menigkatkan kemampuan literasi matematis dan karakter kerja keras siswa.

\section{DAFTAR PUSTAKA}

Arikunto, S. (2010). Prosedur Penelitian Suatu Pendekatan Praktik. Jakarta: PT Rineka Cipta.

Joy \& Anyfalude. (2014). Impact of Discovery-Based Learning Method on Senior Secondary School 
Physics. IOSR Journalof Reasearch \& Method in Education (IOSR-JRME), 4(3): 32-36.

Kemdiknas. (2010). Bahan Pelatihan Penguatan Metodologi Pembelajaran Berdasarkan Nilai-Nilai Budaya Untuk Membentuk Daya Saing dan Karakter Bangsa: Pengembanga Pendidikan Budaya dan Karakter Bangsa. Jakarta: Badan Penelitian dan Pengembangan.

OECD. (2007). PISA 2006: Science Competencies for Tomorrow's World.http://www.oecd.org. (diakses 20 September 2016).

OECD. (2012). PISA 2012 Assessment Framework. http://www.oecd.org (diakses 20 September 2016).

OECD. (2013b). PISA 2012 Results: What Students Know and Can Do-Student Performance in Mathematics, Reading, and Science (Volume I), PISA, OECD Publishing.

http://dx.doi.org/10.1787/9789264201118-en. (diakses 20 September 2016).

OECD. (2013a). PISA 2012 Assessment and Analytical Framework: Mathematics, Reading, Science, Problem Solving, and Financial Literacy. OECD Publishing. http://dx.doi.org/10.1787/9789264190511-en. (diakses 20 September 2016).

OECD. (2016), PISA 2015 Results: Excellence and Equity in Education, PISA, OECD Publishing.(Volume I) http://dx.doi.org/10.1787/9789264266490-en. (diakses 24 desember 2016).

Ojose. (2011). Mathematics Literacy: Are We Able To Put The Mathematics We Learn Into Everyday Use? Journal of Mathematics Education.June 2011, Vol. 4, No. 1, pp. 89-100.

Sugiyono. (2015). Metode Penelitian Kuantitatif, kualitatif dan R \& D. Bandung: Alfabeta.

Wei. L.S. ChunTai, W. (2015). Latent class analysis of students' mathematics learning strategies and the relationship between learning strategy and mathematical literacy. Universal Journal of Educational Research 3(6): 390-395, 20 